Niepodległość. Idee, fakty, perspektywy. W 100. rocznicę odzyskania niepodległości przez Polskę, red. P. Krokosz, S. Romański-Cebula, Kraków 20I9, s. I67-I89

DOI: http://dx.doi.org/Io.15633/9788374388085.09

\title{
Wielka wojna na „Małej Ziemi”. Wybór tekstów źródłowych poświęconych działaniom wojennym na terenie parafii Wniebowzięcia NMP w Niegowici w I9I4 roku
}

\section{Abstrakt}

Opracowanie zawiera wybór siedmiu tekstów źródłowych poświęconych sytuacji na terenie parafii Wniebowzięcia NMP w Niegowici podczas I wojny światowej. W I9I4 roku miała miejsce ofensywa armii rosyjskiej skierowana przeciwko Krakowowi, zamienionemu w silnie umocnioną twierdzę. Wojska carskie zajęły wówczas wiele podkrakowskich miejscowości, w tym Niegowić. Front przechodził tam dwukrotnie - w listopadzie i grudniu I9I4 roku. Pobyt żołnierzy rosyjskich na terenie parafii w Niegowici oraz ich walki z kontratakującym wojskiem austro-węgierskim zostały opisane przez kilkoro naocznych świadków tych wydarzeń. Zachowane do dzisiaj wspomnienia mieszkańców Niegowici i okolicznych wsi stanowią cenne źródło historyczne.

Stowa kluczowe

Niegowić, parafia Wniebowzięcia NMP w Niegowici, I wojna światowa, armia rosyjska, cmentarze wojenne

\section{Abstract}

The great war on "Small Earth". The choice of source texts describing war operations in the area of Assumption of Mary parish in Niegowić in I9I4.

The analysis contains a choice of seven source texts presenting a situation in the area of Assumption of Mary parish in Niegowić during the First World War. In I9I4 the offensive of the Russian army directed against Kraków, 
which was changed into the strongly fortified fortress, took place. The Czar's armies occupied many places around Kraków, among them Niegowić. The battle front passed there twice - in November and December of I9I4. The stay of Russian soldiers in the area of the parish in Niegowić and their fights with counter-attacking Austria-Hungarian army were described by several eyewitnesses. Memoirs of inhabitants of Niegowić and neighbouring villages are the precious historic source are kept till today.

Keywords

Niegowić, Assumption of Mary parish in Niegowić, the First World War, the Russian army, war cemeteries

Kiedy latem I9I4 roku kolejne światowe mocarstwa wypowiadały sobie wojnę, każdy myślał, że do świąt Bożego Narodzenia wszystko się zakończy i będzie można spokojnie siadać do wigilijnego stołu. Najprawdopodobniej nikomu nie przeszło przez myśl, że ów konflikt potrwa aż cztery długie lata i pochłonie miliony ofiar. Dla ówczesnych wojna z lat I9I4-I9I8 była tak wstrząsającym doświadczeniem, że nazwali ją „wielką wojną” czy też „wojną światową”, której z czasem, z oczywistego powodu, dopisano liczebnik porządkowy „pierwsza”. Krwawe starcia z użyciem najnowocześniejszych osiągnięć techniki wojskowej (czołgi, lotnictwo, gazy bojowe) toczyły się zarówno w Europie jak i na innych kontynentach ${ }^{\mathrm{I}}$. Walki wielokrotnie przetaczały się przez większe bądź mniejsze miejscowości, często również przez zwykłe podwórka i domostwa, pozostawiając po sobie śmierć i zniszczenie. Trwałą pamiątką są cmentarze wojenne, na których spoczęli - często wspólnie - żołnierze walczących stron ${ }^{2}$. O wojnie, tej globalnej oraz tej

I Szerzej zob. J. Dąbrowski, Wielka wojna 1914-1918, Warszawa I937; M. Zgórniak, 1914-1918. Studia i szkice $z$ dziejów I wojny światowej, Kraków I987; J. Pajewski, Pierwsza wojna światowa 1914-1918, Warszawa I99ז; A. Chwalba, Samobójstwo Europy. Wielka wojna 1914-1918, Kraków 20I4; A. Chwalba, Wielka wojna Polaków 1914-1918, Warszawa 2018.

2 Szerzej zob. J. Schubert, Austriackie cmentarze wojenne w Galicji z lat 19141918, Kraków I992; Cmentarze wojenne $z$ okresu I wojny światowej w województwie olsztyńskim, opr. W. Kencer, Warszawa I995; O. Duda, Cmen- 
rozgrywającej się w wymiarze lokalnym, czyli na terenie tzw. „małych ojczyzn", pozostają również wspomnienia, niejednokrotnie utrwalone przez naocznych świadków tamtych wydarzeń. Zawierają one wiele szczegółów dotyczących działań wojennych i życia mieszkańców danego terenu w trakcie trwającego konfliktu.

Działania wojenne dotknęły również obszar galicyjskiej parafii Wniebowzięcia NMP w Niegowici³, wchodzącej w skład powiatu wielickiego. Front wojenny przeszedł tam dwukrotnie. Po raz pierwszy miało to miejsce w ostatnich dniach listopada I9I4 roku, gdy idące na Kraków, będący wówczas silnie umocnioną twierdzą4, wojska carskie zajęły istotne pod względem gospodarczym Bochnię i Wieliczkę, docierając z jednej strony aż do wsi Bieżanów (obecnie dzielnica Krakowa)5, a z drugiej niemal do Myślenic. Drugi raz front przeszedł przez parafię w Niegowici jeszcze na początku grudnia tego samego roku, kiedy wojska austro-węgierskie i pruskie odrzuciły Rosjan spod Krakowa i wzięły udział w słynnej operacji łapanowsko-limanowskiej ${ }^{6}$.

Rozgrywające się wówczas wydarzenia na długo zapadły w pamięć mieszkańców Niegowici i okolicznych miejscowości. Owo dwukrotne przejście frontu przez te okolice zostało odnotowane i spisane przez troje naocznych świadków tamtych wydarzeń - ówczesnego proboszcza

tarze I wojny światowej w Galicji Zachodniej 1914-1918, Warszawa I995; R. Frodyma, Cmentarze wojskowe z okresu I wojny światowej w rejonie Beskidu Niskiego i Pogórza, Warszawa I989; R. Frodyma, Galicyjskie cmentarze wojenne. Przewodnik, t. I-3, Warszawa-Pruszków I995-1998; Cmentarze wojenne I wojny światowej po stuleciu. Stan badań i ochrony, red. M. Karczewska, Białystok 20I8;

3 W aparacie naukowym niniejszej publikacji w odniesieniu do oficjalnej nazwy parafii zostanie zastosowany następujący skrót: PWNMP.

4 Zob. J. Bogdanowski, Fortyfikacje austriackie na terenie Galicji w latach 18501914, Kraków I993; W. Brzoskwinia, J. Janczykowski, Zabytki fortyfikacji Twierdzy Kraków. Ochrona i konserwacja w latach 1991-1998, w: Atlas Twierdzy Kraków, seria II, t. I, Kraków I998, bibliografia; H. Łukasik, Twierdza Krakówznana i nieznana, cz. I-4, Kraków 200I-2009.

5 P. Krokosz, Obecność wojsk rosyjskich w Bochni i Wieliczce w 1914 r., „Res Gestae. Czasopismo Historyczne" I (20I5), s. I28-I53.

6 Szerzej zob. Studia z perspektywy stulecia. Bitwa pod Gorlicami, red. S. J. Centek, S. Kułacz, K. Ruszała, Gorlice 2015. 
parafii w Niegowici księdza Kaźmierza Buzałę7, Jana Długosza z Dąbrów (część Niegowici) ${ }^{8}$ oraz Annę Gurbiel ${ }^{9}$ z Nieprześnii ${ }^{\circ}$. Wszyscy z wymienionych widzieli okropności związane z toczącą się wówczas wojną i doświadczyli ich, a ich wspomnienia stanowią bardzo wartościowe źródło historyczne dokumentujące działania wojenne okresu I wojny światowej na terenie Galicji.

$* * * *$

W artykule opublikowano wspomnienia trzech wskazanych powyżej naocznych świadków walk na terenie parafii Niegowić podczas I wojny światowej - łącznie siedem tekstów. Każdy z nich opisał rozgrywające się na przełomie listopada i grudnia I9I4 roku wydarzenia, czyli ofensywę rosyjską i odwrót wojsk austro-węgierskich oraz kontrofensywę tych ostatnich. W relacjach znalazły się informacje dotyczące stoczonych walk, zachowania się przybyłych Rosjan - zarówno odpowiedzialnych za zwiad oddziałów kozackich, jak i pozostałych jednostek liniowych, w tym przedstawicieli oficerów i generalicji - oraz sytuacji po ustąpieniu frontu.

Zasadniczo nie ingerowano w treść zamieszczonych dokumentów, starając się zachować jak najwięcej ich cech oryginalnych. Podtrzymano podział na akapity i wyodrębnione zasadnicze części tekstu. Poprawiono nieliczne błędy literowe, w uzasadnionych przypadkach zmodernizowano pisownię łączną i rozdzielną, a także interpunkcję,

7 PWNMP, Kronika parafialna parafii Niegowić od roku 1893, rkps, t. I, s. 29-37.

8 J. Długosz, Kronika wsi Niegowić, rkps, s. I7-23. Rękopis ze wspomnieniami przechowywany jest obecnie w domu rodzinnym Długoszów w Niegowici przysiółek Dąbrowy.

9 Wspomnienia Anny Gurbiel, w: Księga Pamiątkowa Cmentarza Wojennego nr 338 Nieprzaśnia, rkps, nlb. Rękopis Wspomnień Anny Gurbiel nie zachował się w oryginale. Fragmenty dotyczące wydarzeń pierwszowojennych zostały przepisane przez Irenę Saławę do prowadzonej przez nią Księgi Pamiątkowej Cmentarza Wojennego nr 338 Nieprześnia, którym się opiekuje. Księga Pamiątkowa... przechowywana jest w domu rodzinnym Anny Gurbiel w Nieprześni.

Io Nieprześnia - miejscowość położona ok. Io km na wschód od Niegowici (za rzeką Rabą). 
dostosowując zapis do obowiązujących współcześnie norm językowych. Świadomie natomiast nie poprawiano archaicznych form gramatycznych, właściwych dla języka epoki. Stosowne wyjaśnienia związane z osobami, miejscowościami oraz wszelkimi terminami występującymi w tekście umieszczono w przypisach.

ks. Mieszko Ćwiertnia

I. WSPOMNIENIA SPISANE PRZEZ KSIĘDZA KAZIMIERZA BUZAŁĘ - LISTOPAD IOI4 ROKU

Wojska rosyjskie były już pod Brzeskiem, tam wstrzymywała je armia Lubicica $^{\text {II }}$, wszystko jednak z Bochni i okolic uciekało ${ }^{\text {I2 }}$. Na gościńcu w Bochni ku Gdowowi trzema szeregami ciągnęły się nasze wojska ${ }^{\mathrm{I3}}$, w popłochu i strachu wszystko uwijało się, by nie wpaść w ręce Moskali. O ile tylko można było uniknąć spotkania z wojskami austriackimi, każdy starał się to czynić, bo żołnierze po drogach i polach zabierali konie mimo protestu, siano, zboże, nie mówiąc o tym, że w stodołach po brzuchy konie wojskowe stały w pszenicy. Na próżno odnosiliśmy się do oficerów, wielu z nich bawiło się wśród śpiewów i gry w karty i trunku długo w noc, gdy my truchleliśmy, że przyjdą do nas Kozacy. Znaczenie „cywila” upadło do zera. Nie mówiąc o wszystkich, wielu było grzecznych, ale wielu uważało Galicję chyba za kraj nieprzyjacielski, brano bydło, wozy przemocą - bez zapytania. Dnia 26 listopada przed południem widzieliśmy na gościńcu w Marszowicach ${ }^{\text {I4 }}$ resztki wojsk austriackich. Nastała złowroga cisza, szyldy ze sklepów po-

I I Generał Stephan (Stefan) Ljubičić - dowódca XI Korpusu armii austro-węgierskiej.

I2 Szerzej zob. P. Krokosz, Obecność wojsk rosyjskich..., dz. cyt., I33-136.

I 3 Ks. Buzała, używając słów „nasze wojska”, miał na myśli oddziały austro-węgierskie.

I4 Marszowice - wieś położona na drodze Bochnia-Łapczyca-Książnice-Gdów ok. 2 km na wschód od Gdowa oraz ok. 2 km na południe od Niegowici. 
zdejmowano, także przed urzędem gminnym, pocztowym schowano. Na domach z zewnątrz powywieszano obrazy. Było przykre uczucie, że wszelka władza ustała, że nikt się nie troszczy o mieszkańców, co chce każdy to może robić, a nie masz ani sądu, ani obrony. Władze administracyjne, autonomiczne, urzędnicy - wszystko to uciekło, został chłop tylko, gdzieniegdzie ktoś z inteligencji. Duchowieństwo miejscowe zostało ze swymi parafianami. Ksiądz Oskar Motz, wikariusz, przeniósł się z mą zgodą do Gdowa, gdzie proboszcz był sam jeden, by być dla niego pomocą i towarzyszem niedoli. Ze mną pozostał ksiądz Buda Jan, wikariusz. Ludność szukała pociechy w modlitwie. Przedtem spowiadali się prawie wszyscy, w ostatnim dniu wielu przybyło do kościoła, gdzie od ołtarza dałem wskazówki, jak mają postępować według najeźdźców. Wśród płaczów rozeszli się do domów. Ja tym czasem pochowałem resztki rzeczy kościelnych do piwnicy, obraz Św. Anny wyniosłem i aparata ${ }^{\text {15 }}$ do piwnicy, a obraz Matki Boskiej na wikarówkę. Lękałem się bowiem pożaru. Srebro kościelne: monstrancje, relikwiarze miałem zabetonowane wraz z winem w piwnicy. Tam też schowałem srebro PP. Włodków z Dąbrowicy ${ }^{16}$. Księgi metrykalne i dokumenty parafialne pochowałem w kościele w zakrystii pod posadzką. Konia i źrebaka dwuletniego wysłałem za Rabę do Kozów w Podgrodziư ${ }^{17}$, dwie krowy do Siekierki w Wólce ${ }^{\mathrm{r} 8}$, powóz i wózek schowany był u Surmy w Jaroszówce ${ }^{19}$ i u Bednarza, para zaś koni i 6 sztuk bydła zostało w stajniach plebańskich. Dnia 26 listopada I9ı4 przed południem przybył ks. Migdał, proboszcz w Brzeziu ${ }^{20}$, z księdzem wikariuszem Dankiem. „Przyszliśmy się po-

I5 Aparaty - przedmioty służące do celów liturgicznych, m.in. do urządzenia ołtarza; naczynia, odznaki liturgiczne, paramenty.

I6 Dąbrowica - miejscowość za rzeką Raba, ok. 6 km na wschód od Niegowici.

I7 Podgrodzie - wówczas miejscowość w parafii Niegowić, ok. $5 \mathrm{~km}$ na południowy wschód od Niegowici, pomiędzy miejscowościami Wieniec i Jaroszówka (za rzeką Raba). Obecnie część Wieńca.

I8 Wólka, Wólka Zręczycka - przysiółek wsi Zręczyce, ok. 2 km na południowy wschód od Gdowa.

I9 Jaroszówka - miejscowość za rzeką Raba, ok. 4 km na południowy wschód od Niegowici.

20 Brzezie - miejscowość położona ok. 4 km na północ od Niegowici, 
żegnać - mówi - bo któż wie co nas czeka”. Wśród obiadu dają nam znać, że most na Rabie wysadzony, znak to, że Moskale już blisko. Pieszo natychmiast wybrali się księża do domu do Brzezia. Odprowadziliśmy ich wraz z księdzem Budą ku Krakuszowicom ${ }^{21}$. Przez pola plebańskie idąc, słyszymy strzały karabinowe, do armatnich już prawie przywykliśmy, bo od początku listopada słyszeliśmy je ciągle, tak że okna dzień i noc brzęczały. Wracamy i słyszymy wokoło dworu w Nieznanowicach strzelaninę karabinową, to Kozacy już strzelali do ułanów austriackich. Widzimy wszędzie łuny i pożary wieczorem, a w Nieznanowicach jakiś mały ogień - to automobil austriacki płonie przestrzelony.

PWNMP, Kronika parafialna parafii Niegowić od roku 1893, rkps, t. I, S. 29-30.

\section{WSPOMNIENIA SPISANE PRZEZ KSIĘDZA KAZIMIERZA BUZAEĘ - LISTOPAD I9I4 ROKU}

Na Łysej Górze ${ }^{22}$ były jeszcze austriackie wojska, noc więc jeszcze spędziliśmy spokojnie. Rano dowiedzieliśmy się, że Kozacy już byli w Świdówce ${ }^{23}$. Około południa stoję przed gankiem plebańskim i widzę, jak piechota rosyjska jeden za drugim wsuwa się na podwórze plebańskie. Jeden z żołnierzy rosyjskich zwraca się do mnie z uwagą: „Nie stójcie tu, bo was może kula trafić". Grzeczny, myślę sobie, Moskal, usunąłem się, by z plebanii obserwować Moskali. Szli do szturmu na Łysą Górę, gdzie w okopach była austriacka piechota. Obserwować się nie dało, padła bowiem kula armatnia za stawem plebańskim, a kule karabino-

2 I Krakuszowice - miejscowość położona ok. I km na północ od Niegowici (przy drodze w stronę Brzezia).

22 Wzniesienie znajdujące się po zachodniej stronie Niegowici (w obrębie Niegowici i pobliskich Wiatowic), gdzie 27 listopada I9I4 roku doszło do walk nacierających Rosjan z oddziałami austro-węgierskimi.

23 Świdówka - kiedyś osobna miejscowość, obecnie przysiółek Niewiarowa położony od wschodniej strony Niegowici. 
we świszczały około plebani i stodoły i kościoła, bo Moskale tamtędy szli ku Łysej Górze. Zeszedłem na chwilę do piwnicy, ale chodziłem i zaraz wróciłem do plebanii. Wtem widzę, że Moskale prowadzą do niewoli żołnierzy austriackich i na plebanię. Dwóch Rusinów rozpłakało się i prosiło mnie o spowiedź. Wyspowiadałem ich na korytarzu przy kuchni w obecności żołnierza rosyjskiego Cygana. Zapadał wieczór. Moskale poczęli znosić rannych i rosyjskich, i austriackich żołnierzy. W kancelarii na słomie umieścili szeregowców, a na łóżku w pokoju przy kancelarii kapitana rosyjskiego postrzelonego w nogę i rękę. Żołnierze wołali o rum, o mleko - rumu nie miałem, mleka się dawało, o ile starczyło. Tymczasem na podwórzu Moskale wzięli się do drobiu, zabrali indyki, kaczki i kury, opalali na ogniskach, a ja nawet nie przypuszczałem, że to moje. W nocy rannych wywieziono, a z rana pochowano na plebańskim polu za Szostakiem nad brzegiem przy drodze kilku Moskali zmarłych w różnych domach tej nocy. Rano prosiłem kapitana rosyjskiego w obecności przybyłego oficera rosyjskiego, podobno Polaka, by mi nie czyniono szkody. Przyrzekli, zwłaszcza kapitan, bo Polak oficer nie chciał bardzo ze mną mówić, a nawet przez tego Polaka oficera wręczyli mi 30 rubli jako odszkodowanie. Grzecznie zasalutowali i odeszli z wojskiem. Jem obiad, aż tu woła nas służba plebańska, że żołnierze rosyjscy kradną nam konie. Wybiegłem, siedzieli duraj'24 na obu koniach, chwyciłem za uzdę, ale że żołnierz miał karabin, a nikogo innego z wojskowych nie było, musiałem puścić cugle. Noc z soboty na niedzielę była najstraszniejsza. Wojska regularne odeszły, pozostała tylko we dworze dzicz kozacka. Już około trzeciej po południu chodzili Kozacy co chwila na plebanię i po wszystkich domach wołali jeść. Jeść im się jednak nie bardzo chciało - oni chcieli rabować. Lękałem się o dziewczęta na plebanii, więc miałem chłopca - Natanka Edwarda - syna kościelnego i ten mi wszędzie towarzyszył, a Kozakom donosił chleb i ser. Ksiądz Buda wpada zdyszany i mówi: „Kozacy postanowili tej nocy zrabować plebanię”, tak się wygadali u Tomasza Jelonka gospodarza z Niegowici, pijaka,

24 Od łac. durus - twardy. W tym miejscu chodzi raczej o to, że siedzieli twardo (dziarsko) na koniach. 
który z Kozakami pił. Zarządziłem straż z sąsiadów. Przychylnie się za tym oświadczyli. Nim się jednak zeszli, nadeszło 3 pijanych kozaków. Nieszczęściem była gorzelnia w Marszowicach ${ }^{25}$, gdzie było około I20 hektolitrów spirytusu. Kozactwo, a z nimi i ludność rzuciła się na spirytus - aż oficer podpalił gorzelnię. Tych trzech Kozaków dobija się do plebanii ze strony podwórza. Drzwi były zamknięte. Dziewczęta w pokoju strwożone się pochowały. Kozak woła na mnie - „Wódki!”. Wyszedłem i mówię, że wódki nie ma. Woła o wino. Kazałem wynieść flaszkę. Woła o drugą. Chcąc dać mu odczepne, każę przynieść drugą flaszkę. Nie zadowala się tym. Chce jeden z nich, najtęższy, drzwi wywalić. Chwytam za ramiona Kozaka i mówię: „Nie pójdziesz”. Oglądnął się, schwycił za kindżał ${ }^{26}$, struchlałem, ale w tej chwili zjawił się kościelny i syn grabarza. Obejrzał się jeszcze i odszedł wraz z dwoma towarzyszami. Za chwilę idzie pięciu Kozaków, jeden z karabinem, i z bramy kierują się prosto ku plebanii. Około bramy stało 7 chłopów i nas 2 księży, pytają się Kozacy: „Co to jest?” odpowiadamy: „Warta!”, odeszli i z drugiej strony od pól plebańskich chcą się dostać, ale chłopi za nimi się zwolna posuwają. Kozacy, widząc straż, znikli gdzieś, przeszedłszy ogród organistowski. Nie wiedzieliśmy, gdzie się podziali. Całą noc czuwaliśmy przy kościele i dzwonnicy, mając na oku plebanię i cały ten koniec wsi. Wróciłem na plebanię, poodmykałem szuflady w biurkach i szafy, by zamków przynajmniej Kozacy nie psuli, a służbie i matce poleciłem iść spać nad stajnię. Kozacy co trochę wyglądali, czy

25 Najprawdopodobniej na Korbielowie. Niektórzy starsi ludzie pamiętają, że mówiło się na ten teren „na gorzelnię”. Jej właścicielami była rodzina Schubertów. Pochodził z niej Karol Schubert, późniejszy generał dywizji w czasach II Rzeczypospolitej, w chwili trwania działań wojennych w jego rodzinnych stronach, dowódca I Wiedeńskiego Pułku Piechoty Obrony Krajowej - tzw. Landwehry. W I9I5 roku objął dowodzenie nad 32 Nowosądeckim Pułkiem Piechoty Obrony Krajowej, zob. Seidels kleines Armescheema. Dislokation und Einleitung des k. u. k. Heeres, der k. u. k. Kriegsmarine, der k. k. Landwehr und der königlich ungarischen Landwehr, nr 76, August, I9I4, s. I44-I45, http://www.mlorenz.at/ images/Seidels_Armeeschema/I9I4/Seidels_Armeeschema_I9I4_I44-I45. jpg (24. I I.20I8).

26 Rodzaj długiego noża, w armii rosyjskiej wchodził w skład uzbrojenia oddziałów kozackich. 
straż stoi, myśmy jednak do samych rorat czuwali. Noc była zimna i mglista, a wydawała się nieskończenie długą. Wśród ciszy nocnej słychać było tylko kwik świń w różnych wsiach, to Kozacy przygotowywali sobie uczty. Po odprawieniu rorat, w czasie których także plebanii pilnowali parafianie, zjawia się oficer rosyjski i prosi, czy nie byłoby pomieszczeń dla sztabu dywizyjnego. W smutku pocieszyło mnie to, bo spodziewałem się, że oficerowie ochronią mnie i wieś od napadów i rabunków. Nie było bowiem domu, żeby Moskale go opuścili, wszędzie zaglądali, raz jedni raz drudzy, a co się dało, rabowali. Rzeczywiście oficerowie rosyjscy byli bardzo grzeczni. Z wieloma użaleniami zgłaszali się do mnie ludzie, przedstawiałem je jenerałowi Parczewskojemu ${ }^{27}$. Kazał badać, wysyłał oficerów. Inna rzecz, że moje skargi nie odnosiły skutku, ale czuliśmy się przynajmniej w domu bezpiecznie. Na wikarówce był drugi sztab z jenerałem. Podobno oficerowie tamtego sztabu niewiele warci, kupowali od Kozaków również skradzione konie po 40 rubli. Sztaby te przebywały od 29 listopada do 3 grudnia. Jenerał Parczewski, odjeżdżając do Rudnika czy Sierakowa, bardzo był grzeczny, szli bowiem naprzód i spodziewali się wziąć wnet Kraków. Na pożegnanie częstował mnie herbatą nawet. Dnia 3 grudnia zgłosił się Tereszczenko ${ }^{28}$, późniejszy minister spraw zagranicznych w czasie rewolucji i prosił o gościnę dla oddziału Czerwonego Krzyża, który sam utrzymywał. Przyjąć musiałem. Było w tym oddziale kilku Polaków,

27 Generał Paweł Parczewski - jeden z dowódców rosyjskich biorących udział w popisywanych działaniach wojennych. 26 listopada I9I4 roku jego żołnierze opanowali m.in. Bochnię, zob. P. Krokosz, Obecność wojsk rosyjskich..., dz. cyt., S. I33-I36.

28 Michaił Tereszczenko - pochodził z bogatej rodziny przedsiębiorców branży cukrowniczej z guberni kijowskiej. Absolwent Wydziału Prawa Uniwersytetu Moskiewskiego, gdzie wykładał prawo rzymskie i cywilne. Władał kilkoma językami, m.in. francuskim, niemieckim, angielskim. Zajmował się kolekcjonerstwem dzieł sztuki. Na początku I wojny światowej został wyznaczony przedstawicielem Czerwonego Krzyża i skierowany na front. Następnie w latach I9I5-I9I7 zajmował kilka istotnych stanowisk w strukturach organów wojskowych. W I9I7 roku minister finansów, a następnie minister spraw zagranicznych Rządu Tymczasowego w Rosji. Po przewrocie bolszewickim na emigracji we Francji i Anglii. 
naczelny lekarz - Polak - wielki wielbiciel Rosji (przynajmniej wobec mnie), były dwie panie jako samarytanki i pułkownik - zarządca dóbr siostry cara, jak mnie informowano. Byli to ludzie gładcy i grzeczni, prosili mnie nawet na wieczerzę. Pobyt ich trwał 2 dni.

PWNMP, Kronika parafialna parafii Niegowić od roku 1893, rkps, t. I, S. 30-33.

\section{WSPOMNIENIA SPISANE PRZEZ KSIĘDZA KAZIMIERZA} BUZAEĘ - GRUDZIEŃ I9I4 ROKU

5 grudnia ucieczka Czerwonego Krzyża, wraca sztab z jenerałem Parczewskim w nocy, pozostaje przez dzień, w nocy uciekają. Resztka Moskali pozostaje przez dzień 7 grudnia. W nocy ustawiwszy się około kościoła i drogi na rynek, salwami ustawicznie strzelają, aż około godziny II znikają wszyscy, pokradłszy przedtem sól, spiżarnie, trochę około jednego cetnaru ${ }^{29}$ jęczmienia. Dnia 8 grudnia w święto Matki Boskiej Niepokalanego Poczęcia odetchnęliśmy - około godziny 8 rano zjawiają się ułani austriaccy, przybywa ich kilku witanych radośnie, idzie za niedługo piechota, a wieczorem sztab dywizji z Excelencją Jenerałem Belmontem ${ }^{30}$. Sam jenerał bardzo uprzejmy, tożsamo oficerowie. Żołnierze mniej się spisali, w nocy z 8 na 9 grudnia odbili kłódkę do brogu ${ }^{3 \mathrm{I}}$, gdy przez czas Moskali była nienaruszona (bo wozili z dworu zboże i paszę), zabrali siano, 20 kop owsa, jęczmienia parę

29 Dawna jednostka masy. Miara o wielkości zróżnicowanej: cetnar austriacki = $56 \mathrm{~kg}$.

30 Anton Bellmond Edler von Adlerhorst, I9I4-I9I5 feldmarszałek porucznik. Od połowy listopada I9I4 roku dowódca i I Dywizji Piechoty wchodzącej w skład XI Korpusu armii austro-węgierskiej, zob. W. Szczepanik, Sterkowiec-Dziekanów podczas I wojny światowej, bdw, s. I6, http://brzesko.ws/_brzesko/documents/historia/sterkowiec/ws_dziekanow-279.pdf (25.I I.20I8); A. Schmidt-Brentano, Die k. k. bzw. k. u. k. Generalität 1816-1918, Wien 2007 , s. I3.

3 I Bróg-zabudowanie gospodarcze służące do przechowywania płodów rolnych. 
kop ze stodoły. Zobaczyłem rano pustki, nie było czym żywić krów, musiałem je wojsku sprzedać, za siano ledwie mi zapłacili bardzo licho i to dopiero pod groźbą skargi przed jenerałem. Sztab jednak ıo grudnia cofa się do Bilczyc ${ }^{32}$. Przybywa pułkownik i kieruje bitwą, która trwa do I4 grudnia, największa I3 w niedzielę. Za stodołami plebańskimi, za pagórkami, przy polach plebańskich, na Dąbrowach ${ }^{33}$ baterie z armatami, kule armatnie wciąż świszczą ponad kościół i plebanię. Szczęście, że artyleria rosyjska biła na łąki niewiarowskie ${ }^{34}$ i kule nie dochodziły tylko coś dwa szrapnele pękły nad domem Dziedzica, ale nie uszkodziły domu. Natomiast w Pierzchowie ${ }^{35}$ spalono 64 budynki, w Cichawie ${ }^{36}$, zginęli też w czasie tej bitwy: Piotr Zając w Krakuszowicach $^{37}$, kobieta w Dębinie ${ }^{38}$, dziewczyna w Wieńcu ${ }^{39}$ i chłopiec w Marszowicach ${ }^{\circ}$. W Cichawie bowiem i Pierzchowie byli Moskale

32 Bilczyce - miejscowość na trasie Wieliczka-Gdów, ok. 6 km na zachód od Niegowici.

33 Dąbrowy - przysiółek Niegowici przy drodze w kierunku Liplasu.

34 Nazwa własna, pochodząca od szlacheckiej rodziny Niewiarowskich, posiadającej od dawna w tych okolicach swe dobra, zob. W. Urban, Wieś a plebania, czyli notatnik plebana $z$ Gdowa $z$ lat 1597-1604, "Przegląd historyczny” 83 (I992) z. I, S. 93-IO4.

35 Pierzchów - wieś położona ok. $3 \mathrm{~km}$ na wschód od Niegowici.

36 Cichawa - wieś położona ok. $2 \mathrm{~km}$ na północny wschód od Niegowici.

37 Lat 45, zam. Krakuszowice 46, zginął I 5 grudnia I9I4 roku trafiony odłamkiem granatu, zob. PWNMP, Liber mortuorum pro pago Krakuszowice, rok I9I4, rkps, s. 7I, nr ıo.

38 Dębina - przysiółek podzielony pomiędzy dwie wsie - Krakuszowice i Wiatowice. Położony ok. I, 5 km na północny zachód od Niegowici. Kobieta, o której mowa, to Jadwiga Wójcik, lat 64, zam. Wiatowice 98, zginęła ıo grudnia I9I4 r. od szrapnela (rodzaj pocisku armatniego, który wybuchając w powietrzu raził małymi kulkami ołowianymi), zob. PWNMP, Liber mortuorum pro pago Wiatowice, Rok I9I4, rkps, s. I06, nr 20.

39 Wieniec - wieś położona ok. $3 \mathrm{~km}$ na południowy wschód od Niegowici (za rzeką Rabą). Dziewczyna, o której mowa, to Marianna Węgrzyn, lat I6, zam. Wieniec 44, zginęła Io grudnia rażona odłamkiem rosyjskiego granatu, zob. PWNMP, Liber mortuorum pro pago Wieniec, Rok I9I4, rkps, s. 33, nr 6 .

40 Był to Stanisław Miąsko, lat 9 i pół, zam. Marszowice 33, zginął 7 grudnia trafiony kulą, zob. PWNMP, Liber mortuorum pro pago Marszowice, Rok I9I4, rkps, s. I45, nr 20. 
i do nich też celowała artyleria austriacka. Nareszcie I4 grudnia Moskale się cofnęli i oparli się aż nad Dunajcem, gdzie do I maja pozostali.

PWNMP, Kronika parafialna parafii Niegowić od roku 1893, rkps, t. I, s. $35-36$.

\section{WSPOMNIENIA SPISANE PRZEZ KSIĘDZA KAZIMIERZA BUZAEĘ - GRUDZIEŃ I9I4 ROKU}

Naturalnie, że kwaterunki wojskowe trwały aż do marca, a tak już były przykre, że widok zajeżdżającego żołnierza czy oficera napełniał odrazą i strachem. Wielu z nich zachowywało się wprost ordynarnie, uważali wszystkich, co przetrwali inwazję, za szpiegów lub moskalofilów. Działy się też w Galicji straszne rzeczy, wieszano bez sądu, wielu niewinnie. Opowiadano sobie tylko, że swe niedołęstwo chciano exkuzować4 niby to licznym szpiegostwem. Gdy zbliżała się inwazja, nie pozostał nikt, nie objaśnił żaden z tych panów, jak się ma zachować ludność wobec nieprzyjaciół, gdzie zdrada lub nie. Gdy wrócili, wszędzie wojskowość widziała tylko zdradę, a nawet podobno w Wiedniu głoszono, że „Polacy to zdrajcy". Nie obyło się i bez sądu w parafii, gdzie oskarżono jednego ze Świdówki42 o wskazanie Kozakom pozycji austriackich. Uwolniono go po zeznaniach moich, ks. Budy, Długosza43 i Michalika. Stawać też musiałem jako świadek przed sądem wojennym w Krakowie w obronie Samka, wójta z Marszowic, którego za to, że miał Moskalom wskazać krowy dworskie, postawiono przed sąd za zbrodnię przeciw sile zbrojnej państwa (za przyczyną Kostrzewskiego - rządcy z Niegowici), za co groziła mu śmierć lub dożywotnie więzienie. Uwolniono go w zupełności. Jedną było pociechą to, że uratował się kościół, budynki plebańskie, żeśmy przeżyli te ciężkie chwile, pozostając wśród

4I Usprawiedliwiać się.

42 Dziś część miejscowości Niewiarów.

43 Ojca Jana Długosza, którego wspomnienia zostały także przywołane w niniejszej publikacji. 
swoich w tej ciężkiej niedoli. Pocieszaliśmy się wzajemnie księża sąsiedzi, a Książę Biskup ${ }^{44}$ bardzo się nami interesował. Wybierał się też automobilem do Niegowici, dojechał tylko do Gdowa, z Gdowa do Niegowici nie puściła go wojskowość z powodu strzałów armatnich. Dnia 2 maja I9I5 rozpoczęła się ofensywa austriacka, wiele wojska pruskiego kwaterowało się we wsiach parafii, ofensywa ta wypędziła prawie Moskali z Galicji. Odebrano Lwów po Przemyślu, który się w marcu poddał Moskalom. Została tylko część wschodnia w rękach rosyjskich. Rosja mimo chwilowych sukcesów podnieść się nie mogła. W roku I9I7 wybuchła rewolucja, która cały tron carów obaliła, ogłoszono republikę ${ }^{45}$.

PWNMP, Kronika parafialna parafii Niegowić od roku 1893, rkps, t. I, s. $36-37$.

\section{WSPOMNIENIA SPISANE PRZEZ JANA DEUGOSZA Z DĄBRÓW - LISTOPAD I9I4 ROKU}

Tymczasem front wojenny się zbliżał do nas. Pierwszym zwiastunem był tabor wojskowy, który przybył pewnego dnia i rozlokował się na łące dworskiej nad stawem. Pobiegliśmy więc my młodzież, aby zobaczyć z bliska wojsko. Wojacy, krzątając się koło ognisk, opowiadali niestworzone rzeczy, jak to, że gdy Moskale tu przyjdą, to będą się mścić na wszystkich, że kobietom będą odcinać piersi, i inne bzdury.

44 Chodzi o biskupa krakowskiego, księcia Adama Sapiehę, który wówczas zaangażował się w pomoc ofiarom dotkniętym skutkami wojny, powołując do życia specjalny komitet, przekształcony w Książęco-Biskupi Komitet Pomocy dla Dotkniętych Klęską Wojny, szerzej zob. E. Krupnik, Powstanie i organizacja Książęco-Biskupiego Komitetu Pomocy dla Dotkniętych Klęska Wojny, „Folia Historica Cracoviensia” I4 (20I8), s. I5 I-I94.

45 Chodzi o rewolucję lutową (wg kalendarza gregoriańskiego - marcową) z I9I7 roku, w wyniku której abdykował car Mikołaj II, a władzę objął powołany Rząd Tymczasowy, szerzej zob. L. Bazylow, P. Wieczorkiewicz, Historia Rosji, Wrocław-Warszawa-Kraków 2005, s. 374-383 
Wróciliśmy do domu pod strachem wielkim, szczególnie my młodsi. Nareszcie pewnego dnia listopadowego, pod wieczór, na gościńcu koło wioski Nieznanowice ${ }^{46}$ ukazał się patrol ułanów na koniach posuwający się ostrożnie w stronę Bochni. Zza resztówki ${ }^{47}$ dworskiej w Nieznanowicach ukazał się patrol konny Kozaków rosyjskich, który zaatakował patrol austriacki, ostrzeliwując go z karabinów ręcznych. Ułani austriaccy, oddając kilka strzałów, zawrócili z powrotem i galopem pomknęli w stronę Gdowa. Kozacy ich jednak nie gonili - pozostali na miejscu. Dla nas młodych, patrzących z oddali, z bezpiecznego miejsca, owa potyczka wydawała się nam zabawą - jakby obserwowana na ekranie kina. Noc przeszła spokojnie u nas - nie było wojska austriackiego ani też rosyjskiego. Dopiero rano ukazał się oficer austriacki na koniu w towarzystwie drugiego, pilnie obserwując przez lornetkę polową wioskę Nieznanowice. Na zapytanie, czyśmy tam nie widzieli nieprzyjacielskich wojsk, opowiedzieliśmy o wczorajszej potyczce. Zaraz nawrócili i popędzili w stronę kościoła.

W tym samym dniu, koło południa dopiero, zaczęły pomału, ostrożnie wysuwać się od przysiółka Zielona, na wprost przez pola, już gęstsze patrole kozackie, na konikach średniej wielkości, zwinnych, krzepkich. Ubrani byli w potężne czapy baranie, uzbrojeni w szable i karabinki, byli cery śniadej, wzrok ich - trochę dziki - wywoływał postrach. Jeden z nich podjechał pod sam dom, przystanął, więc ojciec nasz wyszedł do niego z fajką w ustach, z którą się nigdy nie rozstawał. Wówczas Kozak zapytał, czy tu nie ma Austriaka. Na odpowiedź, że nie, zawołał, aby dać „pokurit” fajkę. Ojciec podał mu fajkę. Kozak popalił chwilkę i fajkę oddał z powrotem. Fajka pokoju została wypalona, więc na razie odprężenie w domu nastąpiło.

Za patrolami kozackimi posuwała się piechota rosyjskich wojsk od wioski Nieznanowice, rzeczkami z rowami, a później rowem od przysiółka Zielona w kierunku Niegowici i wzniesienia górzy-

46 Nieznanowice - wieś położona ok. 2 km od Niegowici, na trasie KsiążniceGdów.

47 Reszta gruntu z budynkami pozostała po parcelacji prywatnej własności ziemskiej. 
stego zwanym Łysą Górą. Za tym to wzgórzem postanowiło wojsko austriackie poczynić pewnego rodzaju opór w celu powstrzymania [raczej chwilowego opóźnienia - M. Ć.] marszu wojsk rosyjskich tak przypuszczam z uwagi na małą ilość wojska pozostawionego do powstrzymywania. Zaczęli więc Rosjanie zdobywać ową Łysą Górę z okrzykiem „ura!” Zaczęła się więc strzelanina i po niedługim czasie została Łysa Góra zdobyta kosztem 30 czy 40 zabitych, którzy są pochowani na cmentarzu w Niegowici ${ }^{4}$, i zabraniem do niewoli jednej kompanii Czechów49, którym się widocznie nie uśmiechało umierać za sprawę Austrii. Pod wieczór uciszyło się po tej operacji. Nawet i wojsk nie było na razie więcej rozmieszczonych w naszej miejscowości i wskutek tego były pewne nieporządki w dyscyplinie wojskowej, gdyż wieczorem wałęsało się kozactwo pijane, rabując. Tej to nocy zajechali Kozacy wozami i zrabowali cały zapas wytwórni serów oraz zapasy słoniny, która była tak potrzebna dla utrzymania dwu rodzin podczas działań wojennych. Strata materialna naprzeciw utraty życia jest niczym, jest zerem.

J. Długosz, Kronika wsi Niegowić, rkps, s. I7-20.

\section{WSPOMNIENIA SPISANE PRZEZ JANA DEUGOSZA Z DĄBRÓW - GRUDZIEŃ I9I4 ROKU}

Pewnego razu przyjechał na kwaterę jakiś łącznik wojskowy, którego podsłuchano, jak rozmawiał ze swoim przełożonym. Powiadał,

48 Spoczywa tam łącznie czterdziestu jeden Austriaków (z 55 Pułku Piechoty) i Rosjan poległych w grudniu I9I4 roku, zob. R. Frodyma, Galicyjskie cmentarze wojenne. Przewodnik, t. 3: Brzesko-Bochnia-Limanowa, Pruszków I998, s. IOI-IO2; O. Duda, Cmentarze I wojny światowej..., dz. cyt., s. 349.

49 Według ustaleń autora opracowania prawdopodobnie byli to żołnierze $5 \mathrm{Ba}$ talionu Strzelców Polowych z Ołomuńca (FJB 5), na co wskazywać mogą guziki odnalezione na Łysej Górze przez mieszkańców Niegowici w trakcie prac polowych. Otwarte pozostaje jednak pytanie, z jakiej racji żołnierze tej jednostki znajdowali się w ostatnich dniach listopada I9I4 roku na terenie 
że z twierdzy krakowskiej walą pociskami jak wieprzami5o. Nie długo więc zabawili pod Krakowem, bo gdzieś po czternastu dniach zaczął się odwrót wojsk rosyjskich. [...] Pierwszymi zwiastunami odwrotu spod Krakowa były konne tabory, które stopniowo powiększały się, ciągnąc z powrotem na wschód. Radość była wielka z tego powodu. Nie tylko $\mathrm{z}$ tego powodu, że teatr wojny przeniesie się z naszych terenów, ale że „nasi” górą czyli Austriacy, tak bowiem nasza polska społeczność nazywała okupanta, zaborcę austriackiego. Co było powodem owej przychylności, wtenczas nie rozumiałem z uwagi na mój wiek młody. Przypuszczam jednak, że na to wyróżnienie wpływała długa niewola, która stosunkowo do innych zaborów jak pruski i rosyjski była lżejsza, jak i też słabe uświadomienie wsi polskiej. Niemały wpływ na to wywierała również służba naszych braci i ojców w szeregach austriackiego wojska.

Pewnego popołudnia zajechała kawaleria rosyjska, zwana, o ile się nie mylę, kirasjerzy, uzbrojeni między innymi w długie lance, które sięgały dachu domostw wiejskich ${ }^{51}$. Po zakwaterowaniu się po domach naszego przysiółka, wezwał dowódca tejże jednostki do swej kwatery, która się mieściła w trzecim domu w sąsiedztwie, mojego ojca jako wójta tej gromady. Po zgłoszeniu się mojego ojca do owego dowódcy, któremu towarzyszył pop, czyli ksiądz ruski, został zapytany, jak się czuli w otoczeniu wojsk rosyjskich i czy nie odczuli jakichś przykrości. Nieco ojciec odpowiedział, że na ogół wojska rosyjskie dobrze się obchodziły, jedynie Kozacy dali się we znaki, miedzy innymi że i jego zrabowali. Wówczas dotknięty tym uogólnieniem opinii kozactwa, powiedział pop mojemu ojcu, że tak nie powinno się uogólniać opinii kozactwa, gdyż nie wszyscy Kozacy są tacy, i dodał, że niejeden ojciec ma kilku synów dobrych, a jeden z nich może być złodziejem, za co wszyscy nie

Niegowici, skoro nie wchodziła ona w skład I I Dywizji Piechoty. Być może odwrót wojsk austro-węgierskich uciekających przed „rosyjskim walcem parowym” był tak chaotyczny, że jednostki ulegały zmieszaniu.

50 Prawdopodobnie myślał o pociskach miotanych przez austriacki moździerz o kalibrze $305 \mathrm{~mm}$ produkowany przez zakłady Škoda Werke, zob. A. Zaręba, Chuda Emma. Ciężki moździerz 30,5 cm Škoda w czasie I wojny światowej, Kraków 2006, s. 37-38.

5I Chodzi naturalnie o podjazdy kozackie. 
mogą cierpieć. Następnie zaś dowódca zażądał podwodów konnych na godzinę trzecią rano. Ojciec jak mógł tak się wykręcał, że koni już nie ma, ale to nie pomogło, kilka podwodów musi być. Chłopi jednak, zawiadomieni, pousuwali konie ze stajen, co jednak było zbyteczne, gdyż w nocy, o jakieś trzy godziny wcześniej, wojsko cichaczem opuściło nasz przysiółek, tak że niektórzy domownicy nawet nie słyszeli ich odjazdu. Rano zaś była cisza na ogół, jedynie na kraju przysiółka okopała się drużyna w sile trzydziestu ludzi, którzy mieli za zadanie ostrzeliwanie przedpola celem powstrzymywania patroli. W godzinach popołudniowych ów patrol rosyjski oddał kilka salw w kierunku na zachód i chyłkiem, wskakując do rowu, w kierunku przysiółka Zielona wycofali się. Zaś od strony wsi Liplasu ${ }^{52}$ ukazały się sylwetki patrolu austriackiego, które ostrożnie zbliżały się do naszych domostw, w których mieli zabrać do niewoli pięciu ruskich żołnierzy, którym się już sprzykrzyła wojna i dobrowolnie pozostali, aby się poddać Austriakom, [...]. Strach, jaki padł uprzednio na ludność, czy aby nie będą Rosjanie niszczyć wszystkiego przy wycofywaniu się, stał się bezpodstawny. Oparli się u nas na krótko na linii Raby. Austriacy okopali się na linii Krakuszowice wieś-Niewiarów53-Nieznanowice, mniej więcej, na naszym okolicznym odcinku. Za naszymi domami przysiółka Dąbrowy, należącego do gromady Niegowić, okopała się artyleria polowa, austriacka54, która ostrzeliwała najwięcej wieś Pierzchów, gdzie wywołała pożary od nas dobrze widziane ${ }^{55}$. Na noc wycofywali działa do tyłu, do wsi Liplas, aby się w razie czego zabezpieczyć, sztab artylerii pozo-

52 Liplas - wieś położona ok. I,5 km na południowy zachód od Niegowici.

53 Niewiarów - wieś położona ok. $500 \mathrm{~m}$ na wschód od Niegowici.

54 Najpewniej były to baterie z 32 Pułku Artylerii Polowej ze Lwowa lub, co bardziej prawdopodobne, z I I Pułku Haubic Polowych ze Lwowa, na co wskazywać może wielkość odłamków pochodzących z eksplodujących Io4 lata temu pocisków, jakie ludzie kiedyś znajdywali w czasie prac polowych.

55 U ujścia Stradomki do Raby Rosjanie przeprowadzili kontruderzenie i zajęli Pierzchów. Natomiast na linii Kamyk-Sobolów-Nieprześnia, a także na Zonii i Wichrażu, w Grabinie, Buczynie i Gierczycach-Czyżyczce, toczyły się ciężkie walki m.in. z udziałem doborowych austriackich 3 i 8 Tyrolskich Dywizji Piechoty. W tych bojach zginęło kilka tysięcy żołnierzy obu armii. O tych wydarzeniach wspomina Anna Gurbiel. 
stawał w miejscu na kwaterze u nas. Pewnego razu w nocy powstała strzelanina karabinowa, co tak nastraszyła sztab, że bez butów w skarpetkach na koniach uciekli do wsi Liplas, myśląc rozespani, że front przerwany ${ }^{5}$. Ojciec mój, podzielając zdanie oficerów, złapał aparat telefoniczny i wyrzucił oknem na pole. Za chwilę nadszedł feldwebel ${ }^{57}$, Polak z pochodzenia, i zdziwiony pyta się: „Co się stało?”. Ojciec odpowiedział, jak się rzecz miała i że on wyrzucił, aby nie mieć kłopotu od Rosjan. Feldwebel się śmiał i klął, bo musiał reperować aparat, aby nawiązać łączność. Strzelanina zaś ucichła, sztab powrócił na swe stanowiska. Jednak widocznie przez zagrożenia na skrzydłach front przesunął się na wschód.

J. Długosz, Kronika wsi Niegowić, rkps, s. 20-23.

7. WSPOMNIENIA SPISANE PRZEZ ANNĘ GURBIEL LISTOPAD I9I4 ROKU

Wraz ze starszym rodzeństwem patrzyłam przez okno na wojska, które toczyły z sobą straszny bój na bagnety. Pogoda była piękna, ani deszczu, ani śniegu nie było. Wojska rosyjskie zaatakowały nasze okolice, nastąpiło zderzenie wojska austriackiego z wojskami rosyjskimi, zwanymi wówczas „Moskalami”. Wojska austriackie znajdowały się, gdzie obecnie znajduje się cmentarz ukryty za pagórkiem ${ }^{5}$. Wojska rosyjskie

56 Prawdopodobnie były to strzały dochodzące zza Krakuszowic, gdzie Rosjanie próbowali kontratakować. Polegli wówczas żołnierze - 8 Austriaków z 55 Pułku Piechoty i I4 Batalionu Strzelców Polowych oraz 44 Rosjan (łącznie 8 mogił zbiorowych) - spoczęli na Cmentarzu wojennym nr 333 w Cichawie, zob. R. Frodyma, Galicyjskie cmentarze wojenne..., dz. cyt, s. 99-ıo0; O. Duda, Cmentarze I wojny światowej..., dz. cyt., s. 348.

57 Sierżant w armii austro-węgierskiej.

58 Cmentarz wojenny nr 338 w Nieprześni jest położony pośród drzew na wzgórzu górującym nad stawami rybnymi po prawej stronie drogi, jadąc od Sobolowa. Spoczywa tam stu dwudziestu trzech Austriaków z 59 Pułku Piechoty i pięćdziesięciu jeden Rosjan poległych 5 grudnia I9ı4 roku, zob. R. Frodyma, Galicyjskie cmentarze wojenne..., s. I03-IO4. 
spostrzegły oddział austriacki, porozumiewając się na migi, zauważyli przewagę i uderzyli na wojska austriackie. Rozpoczęła się ogromna bitwa na bagnety. Łomot bagnetów, krzyk, jęk nie do opisania. Jeden z żołnierzy w czasie tej bestialskiej bitwy wołał, prosił (widocznie był Polakiem) „Nie zabijaj mnie! Mam żonę i dzieci!”. Litości nie zaznał. Żaden z walczących żołnierzy nie uszedł żywy. Rosjanie doszczętnie wszystkich wybili, zostawiając trup na trupie. Pamiętam trwogę, strach, które nami wstrząsnęły, słysząc szczęk bagnetów, nieludzkie krzyki ranionych i zabijanych. Po skończonej bitwie wojska rosyjskie odpoczywały. Była noc, księżyc w pełni przepięknie świecił. We wszystkich pomieszczeniach naszego drewnianego domu pokrytego strzechą naniesiono słomy i żołnierze spali jak snopy po udanej ofensywie. W pewnym momencie wpada wystraszony wartownik wojsk rosyjskich. Wydał rozkaz i w paru minutach byli gotowi do ucieczki. [...]. Na drugi dzień po skończonej bitwie na pobojowisku kręcili się miejscowi ludzie, odzierając z butów i odzienia poległych. Ja znalazłam portfel, w którym był rozkład linii morskich z Europy do Ameryki. Portfel przekazałam córce mojej siostry - Irenie Saława59 w I993 roku, a ona dała go delegacji austriackiej. Ale niestety wojna nie oszczędziła niczego. Koni we wsi nie było. Konie zabrano na wojnę. Umarłych trzeba pogrzebać. Dzikie ptactwo - wrony i kruki z przeraźliwym krzykiem unosiły się nad pobojowiskiem. Poległych na razie nikt nie grzebał. Po kilku dniach pojawili się miejscowi chłopi w podeszłym wieku. Mieli ze sobą wóz, a na nim pakę z desek. Do tej paki wrzucali rozkładające się zwłoki, zaprzęgali się sami do wozu i ciągnęli pod górę na oznaczone miejsce zwane „Turkówką”. Tam były wykopane doły, w które kładli jedne na drugim rozkładające się ciała. Przez kilka dni tragiczna, śmierdząca karawana żywych i umarłych poruszała się po naszym polu.

Wspomnienia Anny Gurbiel, w: Ksiega Pamiątkowa Cmentarza Wojennego nr 338 Nieprzaśnia, rkps, nlb.

59 Opiekuje się ona po dziś dzień, mimo ponad osiemdziesięciu lat życia, cmentarzem znajdującym się około stu metrów nad jej domem, na którym spoczywają polegli wtedy żołnierze. 


\section{BIBLIOGRAFIA}

I. ŹRÓDłA ARCHIWALNE

Parafia pod wezwaniem Wniebowzięcia NMP w Niegowici:

Kronika parafialna parafii Niegowić od roku 1893, rkps, t. I.

Liber mortuorum pro pago Krakuszowice, Rok I9I4, rkps.

Liber mortuorum pro pago Marszowice, Rok 19I4, rkps.

Liber mortuorum pro pago Wiatowice, Rok I9I4, rkps.

Liber mortuorum pro pago Wieniec, Rok I9I4, rkps.

Jan Długosz, Kronika wsi Niegowić, rkps.

Wspomnienia Anny Gurbiel, w: Ksiegga Pamiątkowa Cmentarza Wojennego nr 338 Nieprzaśnia, rkps, nlb.

\section{2. ŹRÓD£A DRUKOWANE}

Seidels kleines Armescheema. Dislokation und Einleitung des k. u. k. Heeres, der k. u. k.Kriegsmarine, der k. k. Landwehr und der königlich ungarischen Landwehr, nr 76, August, I9I4, http://www.mlorenz.at/images/Seidels_Armeeschema/I9I4/Seidels_Armeeschema_I9I4_I44-I45.jpg (24.II.20I8).

\section{OPRACOWANIA I ARTYKUŁY NAUKOWE}

Bazylow, L., Wieczorkiewicz, P., Historia Rosji, Wrocław-Warszawa Kraków 2005 .

Bogdanowski, J., Fortyfikacje austriackie na terenie Galicji w latach 1850-1914, Kraków I993.

Brzoskwinia, W., Janczykowski, J., Zabytki fortyfikacji Twierdzy Kraków. Ochrona i konserwacja w latach 1991-1998, w: Atlas Twierdzy Kraków, seria II, t. I, Kraków I998, bibliografia; H. Łukasik, Twierdza Kraków-znana i nieznana, CZ. I-4, Kraków 200I-2009.

Chwalba, A., Samobójstwo Europy. Wielka wojna 1914-1918, Kraków 2014.

Chwalba, A., Wielka wojna Polaków 1914-1918, Warszawa 2018. 
Cmentarze wojenne z okresu I wojny światowej w województwie olsztyńskim, opr. W. Kencer, Warszawa I995.

Cmentarze wojenne I wojny światowej po stuleciu. Stan badań i ochrony, red. M. Karczewska, Białystok 2018.

Dąbrowski, J., Wielka wojna 1914-1918, Warszawa I937; M. Zgórniak, 19141918. Studia i szkice z dziejów I wojny światowej, Kraków I987.

Duda, O., Cmentarze I wojny światowej w Galicji Zachodniej 1914-1918, Warszawa I995.

Frodyma, R. Cmentarze wojskowe z okresu I wojny światowej w rejonie Beskidu Niskiego i Pogórza, Warszawa I989.

Frodyma, R., Galicyjskie cmentarze wojenne. Przewodnik, t. I-3, WarszawaPruszków i995-1998.

Krokosz, K., Obecność wojsk rosyjskich w Bochni i Wieliczce w 1914 r., „Res Gestae. Czasopismo Historyczne” I (20I5), s. I28-I53.

Krupnik, E., Powstanie i organizacja Książęco-Biskupiego Komitetu Pomocy dla Dotkniętych Klęską Wojny, „Folia Historica Cracoviensia” I4 (20I8), s. I5I-I94.

Pajewski, J., Pierwsza wojna światowa 1914-1918, Warszawa I991.

Schubert, J., Austriackie cmentarze wojenne w Galicji z lat 1914-1918, Kraków I992.

Studia z perspektywy stulecia. Bitwa pod Gorlicami, red. S. J. Centek, S. Kułacz, K. Ruszała, Gorlice 20I5.

Urban, W., Wieś a plebania, czyli notatnik plebana z Gdowa z lat 1597-1604, „Przegląd Historyczny” 83 (I992) z. I, s. 93-IO4.

Zaręba, A., Chuda Emma. Ciężki moździerz 30,5 cm Škoda w czasie I wojny światowej, Kraków 2006. 
Szczepanik, W., Sterkowiec-Dziekanów podczas I wojny światowej, bdw, s. I6, http://brzesko.ws/_brzesko/documents/historia/sterkowiec/ws_dziekanow-279.pdf (25.II.20I8);

A. Schmidt-Brentano, Die k. k. bzw. k. u. k. Generalität 1816-1918, Wien 2007 , s. I3. 